\section{HOMO JANUS BULGARICUS}

\section{PSYCHOLOGY AND PSYCHOPATHOLOGY (NOT ONLY) OF BULGARIANS}

ISBN 978-619-7328-12-7

This book will be released in January 2017. It contains foreword, 110 essays, a self-portrait, Praise of snowdrop, 28 science-infiction, an interview and coda, 18 of them presented bilingual - in Bulgarian and English, on a total of 377 pages, 9 of them presented herein.

\section{FOREWORD}

Finally in this hollow, lonely village complete his search. In a small shabby house, the Truth sat nearby the fire.

He had never seen a more old and ugly woman.

- Are you the Truth?

Old, wrinkled witch nodded solemnly.

- Say what have to tell the world? What message to convey?

The old woman spat in the fire and answered:

- Tell them I'm young and beautiful!

\section{Robert Tompkins, "In Search of the Truth"}

In the paradigms of cultural topology, "North-South" and "Mediterranean man-Gothic man" are landscapes with a different style of behavior, of self-identification, of sense of family, country, hierarchy and religion, euphoric, nostalgic and pessimistic thoughts and feelings. Like "all existed before its parts" (Aristotle), in the "Knight of the Sad Image" Miguel de Unamuno wrote: "The soul of a nation brings the future hero before he saw light, anticipate it wandering in her spirit, which is formed and expects its occurrence. The hero is not nothing but individualized collective soul"- Genius loci (spirit of place).

According to Michel de Montaigne (1533-1592) - philosopher and father of essays - human existence, outside its heroic and genius performances, will forever be an "imperfect, unfinished garden." A book with that title was written by Tsvetan Todorova Bulgarian and French philosopher, as he defines himself (who, since 1963, has been living in France). In “The garden” he wrote: "Rock of Sisyphus endlessly rolling back downhill. But the fate

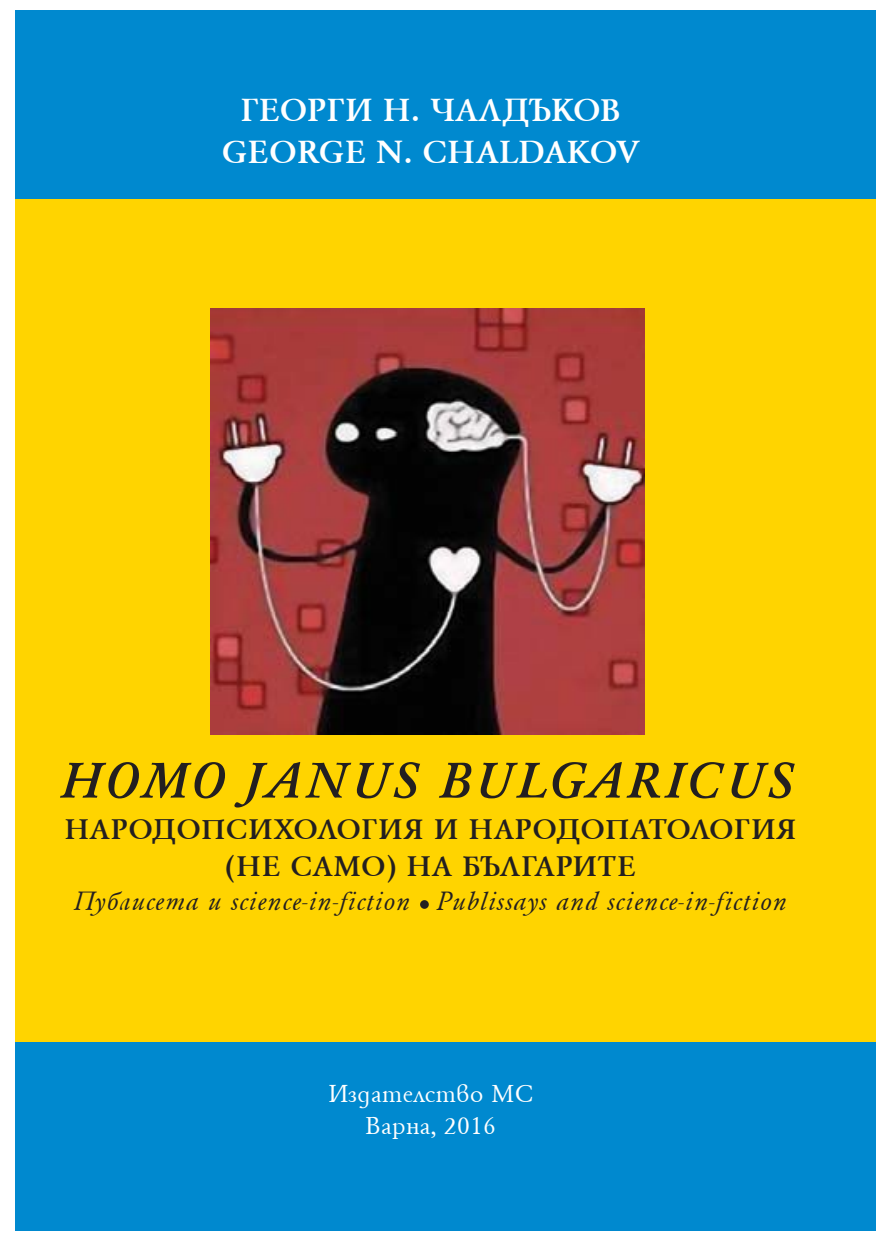

of Sisyphus is not a curse, just such is the human condition that is neither complete, nor perfect. According to Rousseau and Montaigne good and evil flow from one source. However, he believes that improvement is possible."

It reminds me of the ancient Chinese teaching Yin-Yang - every phenomenon contains within itself the opposite of it. Yin-Yang reveals how opposing forces are in fact interacting, interdependent - night (Yin) and day (Yang), dark and light, fire and water, woman and man, moon and sun, sickness and health, death and birth. The Chinese believed that, presented as such, the phenomena and the changes are easy to perceive and explain - as also described in The Book of Ease, also entitled The Book of Changes.

It also reminds me of Janus from Roman mythology, the God of gates (Latin, ianus - way under the arch), of journeys, and of beginnings and ends. This is why Janus is depicted with 
two faces looking in opposite directions. In this book I describe some of the behavioral, mental and emotional manifestations of Homo Janus Bulgaricus - not so much as an individual, but as a community of people (Homines Janus Bulgaricus) - some are well educated, talented, ethical, others - uneducated, selfish, aggressive, politics.

This is not only true of Bulgarians - Homo Janus is a global psychosocial phenomenon. Noteworthy, since "the beginning, long time ago", Yin-Yang and Janus have been incorporating in the behavior of many molecules and cells of the living organisms (1-3).

Dear reader, this book contains acknowledgements, foreword, 110 publissays (publicistic essays), a self-portrait, Praise of snowdrops, 28 science-in-fiction (not science fiction), an interview and coda, 18 of them presented bilingual - in Bulgarian and English, with a total of 68604 words/377 pages and a few photographs, figures and tables.*

September 2016

Burgas-Varna

\section{George N. Chaldakov}

1. Khakh BS, Burnstock G. The double life of adenosine triphosphate. Scientific American 2009; 301: 84-92.

2. Aloe L, Chaldakov GN. The multiple life of nerve growth factor. Balkan Medical Journal 2013; 30: 4-7. DOI: 10.5152/ balkanmedj. 2013.003

3. Another example is Janus kinases - schematically shown on page 377.

* For improving the English in Forward I cordially thank Dr Gill Knight, editorial assistant of the great Geoffrey Burnstock, my Host Scientist in 1991-1992 at RFH School of Medicine and UCL, London University, London, UK.
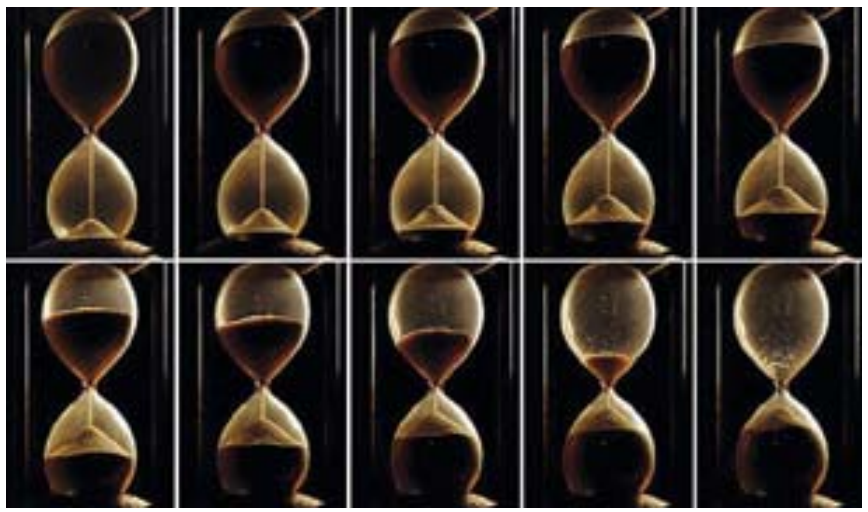

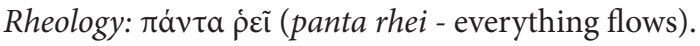

Photography by Nick Chaldakov.

\section{HYBRID PEACE}

E-mail, 8 October 2015, Professor Maria Staykova, Canberra, Australia:

„The brain” - a poem by child from fourth class:

With the brain man thinks that thinks.

Moreover the brain is used for headache.

Located in the head, behind the nose.

When someone sneezes, it drips.

The brain is very sensitive organ.

For this reason people use it rarely.

\section{Facebook, 22 October 2015, Mitko Ivanov, Burgas:}

Presentation of his book „The Silence of Alexander" - Good luck, Mitko! Hopefully, your book about Alexander GeorgievKodzhakafaliyata, the greatest philanthropist of Burgas, will be a lesson (role model) for Bulgarian businessmen. However, „Businessman, owner of theater” and „Businessman, owner of research institute" still sound like jokes in Bulgaria.

E-mail, 4 November 2015, Professor Harold Sacks, Los Angeles, California, USA:

Dear George,

Thanks for sending me your lecture presented on October 28 , 2015 at the 4th International Symposium on Adipobiology and Adipopharmacology in Bucharest. Thinking outside the box is your forte. Let me call your thinking Chaldadipobiology or Chaldology in short.

Harold

\section{E-mail, 20 December 2015, Dr Vesko R. Djendov, Burgas:}

Dear George,

I bought your Cell Biology Textbook - to read it, read it to learn, learn to know! I want to know because I am curious. I am curious because in my $60+$ years gray head always has a seven-year-old boy who wants to know. Sexual satisfaction and the satisfaction of curiosity are the two best human qualities, motivated by a „beautiful egoism”. The rest is „wow, wow” in a different philosophical, political, ethnic and/or religious interpretation. Covering the rough, sharp reactions, reflexes, instincts and social behavior.

V.R.D. - Homo curiosus et personalitatem heterosexualis (HCPH) 
E-mail, 30 December 2015, Professor Arieh Gertler, Rehovot, Israel:

Dear George,

We returned from a 20-day ocean trip to Falkland and South Georgia Islands. And Antarctica, from where I am attaching a few photos of king penguins - colored beauties living together on ice, and elephant seals and humpback whales swimming in the cold water of the South Pole.

Arieh

E-mail, 31 December 2015, Professor Hiroshi Yamamoto, Kanazawa, Japan:

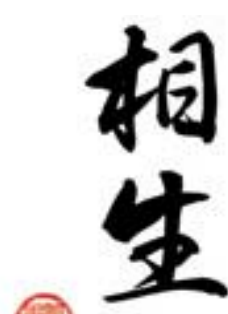

Dear George,

I wish you health, happiness and something fantastic in 2016. Enclosed is my hope for this year - it's called „Sousei”, meaning live together.

Hiro

\section{I immediately replied:}

Hiro, after the wishes for health, your

"Sousei" - to live together in mutual understanding - is the most important message to all people in the world. Because:

Brain and heart are very sensitive organs.

For this reason people should use them more often - together.

George, BHF-ly yours

\section{GAUGUIN'S THIRD QUESTION}

If I do not talk and you do not talk,

this world would break in half, wordless -

unlock my mouth with the key from yours.

\section{Nikolay Kanchev}

In the spring of 1891 the ship „Oceanien” sailed from France to Tahiti. One of the passengers was the great artist Paul Gauguin. Having fallen in love with the exotic estrogen of the island, he transformed his love and melancholy into an amazing spectrum of colors. In one corner of this conceptual painting Gauguin wrote: D'ou venons nous? Que sommes nous? Ou allons nous? (Where did we come from? What are we? Where are we going?) - the most essential questions about the human being. Answer to the first question was given by Charles Darwin on November 24, 1859, when was published his book "The Origin of Species" - we originated from the great apes (hominids). We know neither What are we? - erected monkeys or falling angels, good people or killers of people? Nor „Where are we going?”
- especially now when is dominating the geopolitics of money, global warming, global obesity (globesity), global unjustice. And global terrorism.

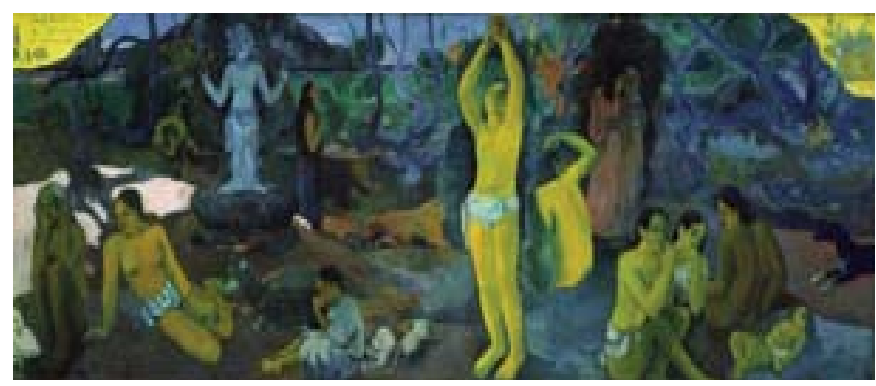

Blessed hedgehogs, they are giving us one of the best answer to the third question of Gauguin - smarter and better educated politicians to apply the strategy of cooperation and mutual understanding for the human well-being, globally. Otherwise the Damocles sword is hanging menacingly over the third question of Gauguin. In the millennial history of human civilization it is not the first time that such critical events to occur. And decisions were often wrong. Ignoring the cannon of symmetry of Leonardo da Vinci, the world is continuing to be an asymmetric globe - educated and illiterated, rich and poor, healthy and sick, respected and neglected. Five million children die annually from hunger in Africa and Asia, some five million overeat are overweight in the USA - one of the most tragic asymmetries. The most hungry and uneducated are in Africa and Asia, well-fed and educated - in the Euro-Atlantic countries. There are thousands victims of terrorism in Africa and Asia, for whom no global empathy was demonstrated compared to that for hundreds victims of terrorism in Europe and USA.

And all that masked by an arrogant political hypocrisy. I wrote more about it in the essay Mondo anti-leonardesco published in “Burgas. Sentimental Stories”. MS Ltd., Varna, 2012. Pages 155157. 


\section{HOMO GRACILIS: LEPTIN, THE OB'S GIRL BORN IN NEW YORK}

Dr Antonio Vito Constantini is an Italian American born in San Francisco, CA 16 years before I was born in Burgas, Bulgaria. In 1990 Toni delivered a lecture at the Biomedical Forum in Medical University, Varna. I showed him my Electron Microscopy Laboratory when he told me that in English, "boat" is not "it", but "she". In the United States, said he, you may address with "she" each object you devotedly love. You can, for example, speak of your microscope as "she is very bright".

Thus, since December 1994, Leptin has becoming my "she", because Leptin is an elegant girl (Greek leptos, meaning thin). And clever - when your stomach is full, she leaves the Adipoland, crosses the BBB and starts playing with brain's NPY, AgRP, MCR4, a-MSH and BDNF, resulting in "stop eating", hence preventing you from obesity and related diseases. We have been pursuing the life and disease of Leptin since the day of her official presentation in Nature 1994; 372: 425-432. Since then now, 31 July 2016, there are 30205 scientific articles dedicated to Leptin. Also more than 20 books were published, and more than 15 symposia organized, including four by the Bulgarian Society for Cell Biology.

Noteworthy, Leptin was elected Miss Scientific World for the year 2009. Because she was still too young, her scientific father - Jeffrey M. Friedman, and her scientific uncle - Douglas L. Coleman, received one million US dollars from the Shaw Prize Foundation, a prize regarded as the Nobel of the East. Before being introduced in Nature, Leptin first appeared in the Laboratory of Molecular Genetics at the Rockefeller University in New York City, NY. Dr Friedman is Head of the laboratory, whereas Dr Goleman brought to Rockefeller obese mice from the Jackson (JAX) Laboratory. "Black on white", two of them shown on page 331 are evidently fat, because their gene encoded for Leptin was deleted (knockouted). Hence these mice cannot produce Leptin and, consequently, has no feeling of satiety, and progressively becomes Mus obesus (mouse obese). This is why the gene was named Obese $(\mathrm{Ob}) . \mathrm{Ob}$ is the biological mother of Leptin. If $\mathrm{Ob}$ gene is defective in humans, you become Homo obesus. Today, there are at least 400 million obese earthicans, representing a huge physical, mental and economic burden worldwide. Arguably, we have to learn more about the life and disease of Leptin, including why sometimes she behaves friendly to our brains and immune and reproductive systems, while being dangerous for our hearts and livers, as highlighted by the great Arieh Gertler in his 2009 book Leptin and Leptin Antagonists.

In 2014 when have prepared my lecture dedicated to Leptin's 20th birthday, I wrote a letter to Jeffrey Friedman, and he replied to me:
"Dear Dr Chaldakov and Colleagues,

Thanks to you for what I believe to be the only birthday party celebrating the anniversary of the cloning of the $\mathrm{Ob}$ gene. I had forgotten entirely that this milestone was about to pass and am grateful to you all for bringing this to my attention. I will now have to organize a party here as well. It is hard to believe so much time has passed. I hope you have a productive and illuminating meeting and wish you the joy of discovery."

The joy of discovery - such a wonderful wish!

\section{CODA}

Natus in Latin means "born”, hence the origin of the word „nation”. Cultura in Latin means „care, breeding”. The care for the born means „culture of a nation”. Reality and shadows in the cave of Plato, holograms, fractals, quarks, bosons, memes, icebergs (hiding the truth), internet, exposome, phenomena and noumena*, things that surround us know everything. Remember: path knows our secrets and the wind knows how salty tears are.

These verses are from the poem "The things that know everything” by Professor Lucian Blaga (1895-1961), the great Romanian poet and philosopher. Thinking in line with him, we want to learn more about "things" that surround us, and about „things” that are inside us - but not everything, because that would be impossible.

Remember also the message of Nichita Stanescu, another great Romanian poet: „The only real things which we take with us in the end are our own feelings, our loves, our hates and adversities. I ask myself: at the end of life, what will we leave outside? I suppose we can leave some feelings, less of hate, some of passion, but... especially of love."

Remember also the parable of the two wolves:

An old man from the American Indian Cherokee tribe shares with his grandson the fight that happens inside the man.

- Son, two wolves are living inside every one of us, and they fight each other. One is evil. It is envy, lies, greed, aggression, arrogance and egoism. Another is good. It is love, honesty, humanity and empathy.

Then grandson thought a little and asked:

-And who is the winner?

- The one who you feed, son - the old man answered.

Remember las dos Espanas - the opposition of democratic and monarchical thinking of the Spanish people, that later lead to the Civil War. I worry that such discord is also expressed by the „two faces of the Bulgarians." However, I believe that we will begin to cooperate for the good of our native Bulgaria. 
Help, God, the Orthodox Bulgarians and protect them for many years to come - resounds the New Year's echo of Cathedral bells and of the giant voice of Boris Hristov, a world-renowned Bulgarian opera singer. ${ }^{* *}$

* Phonemena are the things that we feel with our senses. Things you imagine are noumena (Greek, nous - consciousness, noumenon - it is what we imagine with our thoughts) - similar to thing-in-itself of Immanuel Kant.

** For the improvement in English of Coda I express my cordial thanks to Dr Gill Knight, editorial assistant of the great Geoffrey Burnstock - you know already him from the Foreword. I met Geoff for the first time during Symposium on Vascular Smooth Muscle Cells in Atherogenesis held in 1973 in Heidelberg, Gemany. Professor Burnstock is the most prolific publisher of papers in biomedical science, having 1243 papres, according to PubMed (28 September 2016). He is best known for his discovery of the extracellulat life of the purins (e.g. ATP, ADP) and, accordingly, the purinergic signaling pathways in health and disease. Geoffrey Burnstock is the most cited scientists in biomedicine, having 59083 citations (March 2011) and an h-index of 109. Although the Nobel Committee has not yet appreciated his seminal contibutions, I write the great before his name. 